\title{
Croatian Youth and Populism: A Mixed Methods Analysis of the Populism "Breeding Ground" among the Youth in the City of Zagreb
}

\author{
Augustin DERADO \\ Institute of Social Sciences Ivo Pilar - Regional Center Split, Croatia \\ augustin.derado@gmail.com \\ Vanja DERGIĆ \\ Zagreb, Croatia \\ vanjadergic@gmail.com \\ Vanja MEĐUGORAC \\ Institute of Social Sciences Ivo Pilar, Zagreb, Croatia \\ vanja.medugorac@pilar.hr
}

\begin{abstract}
A number of recent international studies have reported the growing electoral success of populist parties among younger age groups. In this study, authors analysed the "breeding ground" for populism among the youth in Zagreb using the results of the Memory, Youth, Political Legacy and Civic Engagement (MYPLACE) project in Croatia. A mixed methods approach was employed with thematic analysis of 61 semi-structured interviews and regression analysis on a survey sample data of 1,216 young people aged 16-25. Qualitative analysis indicated analogies to Cas Mudde's three core concepts of populism (the "good people", the "bad elite" and the "general will") among interviewees" opinions. In addition, common ideological features of populism (nationalism and radical egalitarianism) were to a degree present among the interviewees' attitudes. In the quantitative part of this paper, the authors narrowed the analysis of populism to the radical right variant of populism, and - given the lack of prominent populist actors in Croatia - to support of ideas rather than political parties. The attitude towards a political system with a strong leader not constrained by parliament was chosen as the outcome since it holds significant populist potential in contemporary democracies. Analyses showed the connection of the anti-elite, anti-systemic attitudes - as well as authoritarianism and a few right-wing political attitudes with the strong leader preference. Both qualitative and quantitative results of this study indicated that the "breeding ground" for populism exists among the youth in Zagreb. Additional research is required to further examine that complex and previously unexplored topic.
\end{abstract}

Key words: youth, populism, democracy, authoritarianism, radical right populism 


\section{Introduction}

\subsection{Populism and democracy - A complex relationship}

Populism widely considered to be an elusive phenomenon and, due to the complex relationship it has with the concepts of democracy and the "people" (populus), it is often (mis)used in public and media discourses about politics. ${ }^{1}$ In the scientific discourse, it is still, to a degree, a contested concept, and theorists consider it to be a political strategy (e.g. Weyland), a special kind of ideology (e.g. Mudde) or even the very logic of the political (e.g. Laclau). ${ }^{2}$ Throughout this study, authors combine insights from perspectives formulated by Laclau and Mudde, using Laclau's work as a broader way to think about populism and Mudde's minimal approach to operationalise and investigate the empirical reality regarding the phenomenon.

In Mudde's (2004: 543) influential approach, populism rests upon three core concepts: the "good people", the "bad elite" and the "general will". Populist political actors claim that politics should be a "crystallisation" of the united political will, a true manifestation of the unambiguous will of the people. Populists proclaim that only they can directly and unequivocally represent the people, in a manner seemingly free of politics in the form of "business as usual". They strive to make an ideological divide in society, a distinction between two unrealistically homogenised groups: "us" - the good and the righteous "people" (which includes the populist actor), and "them" - the bad and corrupted "elite". In that interpretation, the "bad elite" are basically all the other "players" in the political field, usually combined with some further "unwanted others", such as immigrants or minorities (primarily in the radical right variant of populism), or big finance/ multinationals (common in the radical left variant of populism; e.g. Zaslove, 2008; Mudde, 2004; Mudde and Kaltwasser, 2013; Meny and Surel, 2002; Albertazzi and McDonnell, 2008; Panizza, 2005).

\footnotetext{
${ }^{1}$ In Croatia, the term "populism" appears in various contexts, amongst which are "as a rhetorical instrument aimed at the disqualification of the political opponents; in media discourse as the inflammatory label attached to disparate phenomena; as a political identification of those politicians which try to envision an image of activist close to the people and opposed to the obnoxious political elites" (Zakošek, 2015). Only the last one is close to the strict scientific definition of what populism in its pure form really is. In media use, the explanation of the word "populism" is usually missing.

${ }^{2}$ For the discussion on differences between theoretical perspectives on populism, see Kaltwasser (2012) and Gidron and Bonikowski (2013).
} 
Populism thrives during periods of crisis, and it has been established that "some degree of [crisis] is a necessary precondition for populism" (Laclau, 2005b: 191). This is particularly true in a crisis of political representation, during which great parts of the population feel that their interests and demands are not being represented in the political arena (e.g. Mouffe, 2013). Contemporary populism is an exceptionally relevant phenomenon, and the results of the elections for the European parliament in 2014, as well as the results of many populist parties at national elections, are apparently a herald of the "new strength" of populist forces in Europe (Mudde, 2015).

Laclau argues that populism requires two conditions to arise: "the dichotomisation of the social space through the creation of an internal frontier" (the "us" and "them" divide) and "the construction of an equivalential chain between unfulfilled social and political demands" (Laclau, 2005a: 38). The link between unfulfilled social and political demands is dependent upon the construction of floating or empty signifiers (Laclau, 2005b). Signifiers are, according to Laclau (2005b), the condensations of some aspects of popular identity that signify the chain of unfulfilled demands and unite them in a political idea. They are built around common symbols and ideological constructs with great political power in a given society.

Thus, while it relies on a small number of core concepts (Mudde, 2004), populism needs to have core ideological contents and is often defined as a "thin-centred ideology" (Freeden, 1998). Ideologies like nativism, neoliberalism, imperialism and radical egalitarianism power its signifiers and arise from them. Because of the heterogeneity of possible core contents and signifiers, populism is necessarily a very diverse phenomenon, displaying high dependence on the specific political and cultural context.

Regarding the diversity of forms of populism, it is not surprising that there are different interpretations of its character. Certainly, to regard populism as exclusively an "underside of democracy" (Panizza, 2005) would be wrong; as famously put forth by Laclau (2005b: 67), populism is a component of all politics, the very "political logic" (Laclau, 2005b: 117). One way of achieving more clarity is to make an ideal-typical distinction between populism in "mainstream politics" and populism in radical politics. By radical politics, we mean the politics that is opposed to fundamental values of liberal democracy (Mudde, 2007). Radical populist actors fit into the three aforementioned populist core concepts (Mudde, 2004) and bring 
about the described radicalisation of the political (and social) field. Populists in mainstream politics, despite using some of the common populist tactics, hold on to the pluralist political system of liberal democracy and the representative institutions and do not strive for the radical dichotomisation of the political space. ${ }^{3}$

Regarding its ideological contents, European populism in the 2010s is in most cases a phenomenon on the political right, exclusionary in its character, which mobilises on grievances over ethnicity and immigration and combines populism with nativism (or radical nationalism) and some forms of authoritarianism (Rydgren, 2007; Mudde, 2007). Populism on the political left has so far been less frequent and less important in Europe. ${ }^{4}$. However, parties like SYRIZA in Greece and Podemos in Spain have shown that left, liberal and inclusionary populism can gain nation-wide support (Stavrakakis and Katsambekis, 2014; Tsakatika and Eleftheriou, 2013), albeit faced with great difficulties when they gain power (e.g. the case of SYRIZA). However, because both types of populism exclude and include parts of the population, ${ }^{5}$ it is important to be aware of the complexity of the labels "left" and "right" and "inclusionary" and "exclusionary" in the context of populism.

The role of the strong and charismatic populist leader is particularly important for the phenomenon of populism (Canovan, 1999; Panizza, 2005; Laclau, 2005a; Albertazzi and McDonnell, 2008). Populist leaders usually present themselves as having a direct link to the "people", a connection which seemingly enables them to represent the "general will" in a manner that strives to bypass representative democratic processes (Panizza, 2005; Arditi, 2005), and in that sense, the institution of the parliament and the liberal-democratic system of "checks-and-balances". A populist leader can become the centre of the entire political project, to the point that the ho-

\footnotetext{
${ }^{3}$ Among the common mainstream populist tactics are special identification and calls upon the people, attempts to construct a special link with the people as a homogenised group, efforts to win over large populations by saying "whatever the people want to hear" (Arditi, 2005), the use of popular signifiers in political discourse (Laclau, 2005b) and the use of media in tabloid-like politics (Canovan, 1999).

4 Aside from the three populist core concepts, left populism usually shares values of anti-neoliberalism, social justice, some variant of social democracy and a welfare state or democratic socialism and acknowledgment of ecological and gender issues (March and Mudde, 2005; March, 2012).

${ }^{5}$ For example, the welfare chauvinism ideology is common for radical right populism in Europe (Mudde and Kaltwasser, 2013: 167).
} 
mogenising function of the populus is "carried out [only] by a pure name: the name of the leader" (Laclau, 2005a: 40).

In its radical form, populism can be regarded as a warning signal about the weaknesses, under-represented demands and passions in a given democratic system (Mouffe, 2013). It can be "both a threat to and a corrective for democracy" (Mudde and Kaltwasser, 2013: 168). However, we must not forget that, according to Laclau (2005a, 2005b), every political project is in a way populist.

This study is focused on examining the demand-side analysis of populism among the youth in Zagreb, the Croatian capital. A potential demand is a necessary but not a sufficient condition for the success of populists (Van der Brug, Fennema and Tillie, 2005) because the other half rests on supply-side explanations, which deal with the internal dynamics of populist parties, the role of the populist leader, as well as the broader political opportunity structure (a complex mix of institutional, political and cultural factors; Mudde, 2007; Norris, 2005). In that regard, demand-side analysis tries to "explain why and which people constitute the potential electorate of populist" parties (Mudde, 2007: 230).

\subsection{Populism and democracy in Croatia}

Populism is an under-researched phenomenon in Croatia. Only a few authors have published papers dealing with the concept (e.g. Milardović, 2004; Zakošek, 2010; Šalaj, 2012; Grbeša and Šalaj, 2014). Milardović (2004) holds that Croatia had three types of populism in the 20th century: the right-wing populist dictatorship of Ante Pavelić during the Independent state of Croatia period (1941-1945), the left-wing populist dictatorship of Josip Broz Tito during the socialist Yugoslav "Tito period" (1945-1980) and the semi-democratic/semi-authoritarian populism during the Franjo Tuđman period (1991-1999). The "Tuđman period" is closest to what was considered populism in the 2010 s, because it was part of a national state democratic multi-party political system. Mudde (2007: 280) states that the rule of Franjo Tuđman as the strong leader in a semi-presidential system was a rare example of the populist radical right government in Europe. However, this case was "highly specific, as the country was in a defensive war for most of that period, and many of the most negative aspects of the regime were at least in part a reaction to largely similar actions and attacks by Milošević's Yugoslavia/Serbia" (Mudde, 2007: 279-280). 
The authoritarian socialist legacy, the formidable task of triple transition $^{6}$ after the destructive war (1990-1995), the semi-democratic populist government legacy from the time of war and in the war's aftermath and the rise of ethno-nationalism and conflicts provoked after the breakup of Yugoslavia all together make a fertile "breeding ground" for populism in Croatia. Nevertheless, at the time of the signing of the European Union accession treaty in 2011, the democratisation of the political actors and democratic consolidation was evident (Dolenec, 2013). One of the most important factors in Croatian democratic consolidation was the role of the European Union (Dolenec, 2013; Beširević, 2012) as a powerful external factor for democratisation and liberalisation, both political and economic (Mudde, 2002; Merkel, 2004).

Still, due to its elusiveness, populism can go "under the radar", and the first supply-side empirical research on populism in Croatia (Grbeša and Šalaj, 2014) used content analysis of interviews given by Croatian politicians. Grbeša and Šalaj (2014) concluded that in the period of 2009-2015, there were few "real" populist political figures: Ivan Grubišić, Željko Kerum, Milan Kujundžić and Ivan Vilibor Sinčić. Additionally, analysis has found that Milan Bandić, a highly influential Croatian politician, ${ }^{7}$ is a border case between a "real" populist and a mainstream populist. Recent developments in the Croatian political field have shown the rise of the first populist political party, Živi zid. ${ }^{8}$ For a few months in 2015 (January-May) the polls gave the third ranking in Croatia to a political party practically without political experience and with very strong anti-institutionalist discourse. However, several months before the November elections, voters shifted their (protest) vote to others, resulting in only one seat in the 2015 parliament.

In conclusion, it can be said that the Croatian political space recently started to show high volatility, and that populist protest parties (particularly

\footnotetext{
${ }^{6}$ See, for example, in Offe and Adler, 1991.

${ }^{7}$ Milan Bandić is a four-term mayor of Zagreb and runner-up in the 2010 presidential elections.

${ }^{8}$ Political programme of Živi zid [Human Shield] and its leader Ivan Vilibor Sinčić can be described as radical and populist, combining left and right ideological components in a strong critique of political and economic elites, European union and capitalism. Živi zid called upon "ordinary people" or "impoverished Croats" in the crunch of foreign big-money interests for its legitimacy. Ivan Vilibor Sinčić advocated the restoration of the semipresidential system in Croatia and quoted Victor Orbán and Vladimir Putin as influences (thus displaying certain authoritarian tendencies), but also Mahatma Gandhi (Kasapović, 2015).
} 
the mainstream, but also the radical ones) proved that they can be at least moderately successful.

\subsection{The youth in Croatia and politics}

Croatian citizens who were born at the end of or after the 1980s have little experience of the populism and political radicalism of Croatia's recent past. They were born in the years strongly shaped and influenced by the Homeland War $^{9}$ (1991-1995) and by the transition from the socialist political system to the parliamentary democracy. They have experienced a troublesome ethno-national, political and economic transition period that has continued throughout the $1990 \mathrm{~s}$ and the beginning of 21 st century. These political and structural changes have placed young people into an ambivalent situation towards the future, making them known as the "sceptical generation" (Tomić-Koludrović, 1999) or even more directly "the losers" (Ilišin, 2004).

Young people in Croatia face economic crisis and an unsecure future, with the third greatest youth unemployment rate in the European Union, with only Greece and Spain having higher rates at the time this research was undertaken (Eurostat, 2014). Some studies (e.g. Mustapić and Karajić, 2013) have indicated that unemployment and economic crisis are the two main issues young people emphasised as the most distinctive problems present in contemporary Croatian society. These are among the main reasons for youths' aversion towards Croatian political parties and alienation from politics in general, which leads young people to declare themselves "apolitical" (Mustapić and Karajić, 2013).

Furthermore, studies show (Ilišin, 1999, 2004, 2006; Gvozdanović, $2011,2014)$ that young people are politically marginalised in terms of their political participation in government institutions and political organisations, and they have very low overall trust in institutions (Sekulić and Šporer, 2010; Ilišin et al., 2013; Franc and Međugorac, 2015; Gvozdanović, 2015). Partly because of these factors, there is a low level of political participation of young people (Ilišin, 2004) and a lack of certain types of civil activism among the youth (Franc, Šakić and Maričić, 2007). In addition, most

\footnotetext{
9 The Homeland war (or the War for Croatian Independence) was a part of the Wars of the Yugoslav secession or the Yugoslav wars (1991-2001). As scientific debate on the terminology is still in progress, the authors have decided to employ the term most commonly used in the Croatian political and public discourse, the Homeland war.
} 
of the young people in Croatia think that their generational interests are poorly represented (Ilišin et al., 2013; Gvozdanović, 2014), which could be related to Laclau's idea of the chain of unfulfilled demands that is a perquisite for the rise of populism. Ilišin and her associates (2013) clarified that poor participation by the youth in formal politics is not replaced by greater involvement in civil society; rather, it indicates increasingly apolitical attitudes toward modern politics. Moreover, speaking about democratic potentials among young people, Ilišin (2015) referred to the paradox of having young people that are raised in a democratic political system, but show declining support for democratic order. Thus, young people without much political experience could be a group more open to voting for "protest parties" and populist actors because they are alienated from the political system. Furthermore, youth are under the processes of precarisation and rising insecurity, which can also lead to voting for radical political options (Norris, 2005). Various studies have found that the right-wing populists have more electoral success among younger age groups (Zaslove, 2008; Werts, Scheepers and Lubbers, 2012), as well as amongst those who are unemployed (Werts, Scheepers and Lubbers, 2012).

\subsection{The aims of the study}

This study aimed to explore the inclinations to populism among young people and to understand their sources, i.e. to establish whether there is a "breeding ground" for populism among youth in Zagreb. To the best of the authors' knowledge, this is the first demand-side study of populism in Croatia. This study draws upon the methods and results of the Memory, Youth, Political Legacy and Civic Engagement (MYPLACE) project, a mixed methods research effort.

Qualitative analysis of semi-structured interviews was the foundation of the study, and these interviews were used to examine various components of youths' opinions and inclinations towards populism, namely:

a) interviewees' perception of populism and populist strategies in mainstream politics;

b) the analogies to the three core concepts of populism as formulated by Mudde (2004);

c) the perception of the "usual suspect" ideologies (e.g. nativism, neoliberalism, radical egalitarianism), which are the possible contents of 
populism (Mudde, 2004) and can also be regarded as the "inspiration" for the creation of signifiers (Laclau, 2005b);

d) the support for the idea of a strong leader of the state who is above the usual political process, and is, in a way, not constrained by the institution of parliament, which is a very important component of radical populist politics (e.g. Canovan, 1999; Panizza, 2005; Laclau 2005b; Albertazzi and McDonnell, 2008).

In the quantitative part of the paper, analyses were narrowed and focused to a single dimension of populism, its radical right variant. Due to the politico-historical moment in which the MYPLACE project was conceptualised (2010-2011), the survey section on populism aimed primarily to capture the radical right dimension of the phenomenon. ${ }^{10}$ Conceptually, it adopted Mudde's (2007) characterisation of radical populist right ideologies as combining nativism, populism and authoritarianism, clearly displaying the complexity of capturing the phenomenon of populism using the survey methods. ${ }^{11}$

The existing international literature on the quantitative aspects of the demand side of populism is based largely on past voting patterns or voting intentions of the general population. However, because there were no prominent radical populist parties at the time of the survey in Croatia, the authors decided to move from the terrain of the support for parties to the support of ideas. Accordingly, the aim of the quantitative analysis was to examine the associations of a battery of radical right populism indicators (the predictor variables) to the type of political radicalism that supports a political system with a strong leader not constrained by parliament (the outcome variable). The authors interpreted support for such a system as an inclination towards authoritarian rule and, thus, a radical political system that can be formed on a substantial populist core, or, in other words, can use a populist mode of communication/mobilisation. Radical right populist leaders in developed democracies usually attempt to hide their authoritarian leadership strategies under the idea of the "will of the people", aiming to legitimise themselves as the only "true" democrats. It is

${ }^{10}$ It was a time marked mainly by right-wing populism (in Europe and North America) and studies followed the political reality to a degree that many authors in the West have interpreted the phenomenon of populism as inseparable from radical right politics.

11 A more detailed operationalisation of the phenomenon of populism was proposed by Akkerman, Mudde and Zaslove (2014). 
recognised that populism "emerges from within democratic politics, [...] as a 'misfire' whereby populism can morph all too easily into authoritarianism" (Arditi, 2005: 77). Moreover, populist projects, by the power of the cult of personality, "can transform leaders into quasi-messianic figures for whom accountability is not a relevant issue, and the populist disregard for institutional checks and balances can encourage rule by decree and all sorts of authoritarian behaviour while maintaining a democratic façade" (Arditi, 2005: 95).

Given the strength of populist actors across Europe on the one hand, and on the other hand recognising the broad legitimacy that the idea of democracy still holds, particularly in the European Union as the promoter of democracy, the most probable type of radical or "border-democratic" project for Croatia is also some form of populism. As already emphasised, radical right populism is just one dimension of populism. That is the reason for embedding the quantitative part of the analysis into the broad qualitative interpretative findings the study.

\section{Method}

\subsection{Research project}

This study drew upon the methods and data from the MYPLACE project, an international Framework Programme 7 (FP7) project (2011-2015). ${ }^{12}$ Research was conducted in 14 European states and included 16 scientific institutions. The main research goals of the project were to examine inclinations towards totalitarianism and populism among European youth, as well as their understanding of civic and political needs, opportunities and perspectives. The target group was young people aged 16 to 25 . That age group is of particular importance for the populism research as Europeans younger than 25 did not directly experience radical political systems. MYPLACE has utilised a mixed methods approach. In the following sections its quantitative and qualitative methods are briefly described.

\subsection{Quantitative method}

In each of the 14 countries involved in the MYPLACE project, two contrasting locations were selected for conducting the quantitative part of the research. In Croatia, a survey was conducted in two districts of Zagreb,

\footnotetext{
${ }^{12}$ For more information about the project: http://www.fp7-myplace.eu/concept.php. For reports and resources for researchers: https://myplaceresearch.wordpress.com/reports/.
} 
Podsljeme and Peščenica. For the purposes of this research, these locations were not treated as two subsamples but as a single research unit. ${ }^{13}$ Random sampling was used on both locations, based on lists derived from administrative sources. Attempts to conduct individual surveys were made by visiting the households, and in order to minimise non-response, a minimum of three contact attempts was made. The survey was conducted from September until December 2012 on a total of 1,216 participants. ${ }^{14}$

\subsection{Qualitative method}

The qualitative approach of the MYPLACE project was informed by Burawoy's (2009) extended case method. The qualitative part of the research employed various techniques, including semi-structured interviews designed to capture the meanings that young people in Zagreb attach to their social and political attitudes. ${ }^{15}$

Following the end of each survey, participants were asked to participate in an interview. If they agreed, their survey results on questions of tolerance/liberalism and political participation were examined, and according to these two criteria, a maximum variation interview sample was pursued (e.g. Creswell, 2013). The interview sample was broadened by

${ }^{13}$ Two locations were selected in order to capture social class differences among youth. Podsljeme is an affluent Zagreb district, whereas Peščenica is among the least well-off districts. Subsequent analyses showed that the two locations do not significantly differ with respect to social class $\left(\chi^{2}(3)=4.85, \mathrm{p}>0.05\right)$, which was derived from mothers' and fathers' education and occupation levels. However, differences between the two locations were established in measured attitudes. Specifically, in comparison with youth from Peščenica, youth from Podsljeme were more prone to violence justification $\left(\mathrm{M}_{\text {Podsljeme }}=\right.$ $\left.13.3, \mathrm{M}_{\text {Peščenica }}=12.0 ; \mathrm{t}(1092)=2.69, \mathrm{p}<0.01\right)$, had higher trust in national institutions $\left(\mathrm{M}_{\text {Podsljeme }}=18.9, \mathrm{M}_{\text {Peščenica }}=17.2 ; \mathrm{t}(1160.4)=2.86, \mathrm{p}<0.01\right)$, were more satisfied with the way democracy works in Croatia $\left(\mathrm{M}_{\text {Podsljeme }}=5.1 ; \mathrm{M}_{\text {Peščenica }}=4.4, \mathrm{t}(1167.0)=4.95, \mathrm{p}\right.$ $<0.01)$, had more positive attitudes towards the role of religion in politics $\left(\mathrm{M}_{\text {Podsljeme }}=1.7\right.$, $\left.\mathrm{M}_{\text {Peščenica }}=1.3 ; \mathrm{t}(1130.2)=4.88, \mathrm{p}<0.01\right)$ and had less positive attitudes towards minority groups $\left(\mathrm{M}_{\text {Podsljeme }}=11.7, \mathrm{M}_{\text {Peščenica }}=12.5 ; \mathrm{t}(1004)=3.19, \mathrm{p}<0.01\right)$. For these reasons, the effect of location on preference for a strong leader was controlled for by including it in the first step of the regression analysis.

${ }^{14} 610$ participants were from Podsljeme (the contact rate of $69.8 \%$ and the response rate of $45 \%$ ) while 607 were from Peščenica (the contact rate of $49 \%$ and the response rate of $36 \%$ ).

${ }^{15}$ Interviews were designed around six thematic sections: political heritage and transmission, history and memory in everyday life, participation and understanding of "the political", culture and lifestyle, the language of politics and receptivity to populism/extremism. The questions followed a uniform project frame but were adjusted to the cultural and political specifics of every country and thus extended with specific questions and prompts. 
adding several members of the largest two political parties (HDZ and SDP) ${ }^{16}$ youth wings, youth active in city councils and several Roma interviewees. Thus, the sampling procedure corresponded to a variant of the purposive sample (Yin, 2010). From the beginning of January 2013 until the end of April 2013, a total of 61 interviews were conducted, with an average length of 77 minutes. Interviews were conducted at participants' homes or on the premises of the Institute of Social Sciences Ivo Pilar. Interviewees received a USB drive, both as an incentive and a gesture of gratitude for their time. Two of the study authors conducted data coding using NVivo 9 software. A primarily inductive approach was employed. Coded text was arranged into categories through the process of conceptual refinement.

Regarding generalisibility of qualitative results, it is reasonable to interpret the findings in the perspective of Yin's $(2003,2010)$ analytical generalisation, in which "investigators show how their study's findings are likely to inform a particular set of concepts, theoretical constructs, or hypothesized sequence of events" (Yin, 2010: 100). Additionally, naturalistic generalisations can be considered for this kind of approach and topic, i.e. generalisations by which "people can learn from the case [or multiple cases] either for themselves or to apply to a population of cases" (Creswell, 2013: 163). Naturalistic generalisation, which is sometimes called "readers generalisability", shifts the responsibility for making generalizations from the researcher to the reader (Maxwell and Chmiel, 2014).

\section{Qualitative analysis results}

In this section, the results of the qualitative analysis of interviews are presented, organised by theory-inspired points of concern as outlined in the aims of the study section.

\subsection{The search for the "breeding ground" for populism: Croatia - A country of mainstream populism?}

Only a minority of interviewees were familiar with the term populism, and they almost exclusively related it to mainstream populism. Although they were not familiar with the term, many of our interviewees recognised and

\footnotetext{
${ }^{16} \mathrm{HDZ}$ is the acronym of the political party Hrvatska demokratska zajednica (Croatian Democratic Union) and SDP is the acronym of the political party Socijaldemokratska partija Hrvatske (Social Democratic Party of Croatia).
} 
condemned a few of the most common populist tactics (or components of the populist style of communication) found in mainstream politics, as in these examples:

During those general election campaigns, they promise everything, they "promise the moon" "castles and fairies", and when they are elected and gain power, all those issues which they promised to solve, half of those issues, they forget about them. (Majda)

You can see the parties that are selling their image, but, then again, it all goes up in smoke to me. (Majica)

In political parties, there's a lot of populism too, I think in particular in HDZ. [...] It's a problem, but I doubt it can be resolved; that's like a necessary evil to me. Populism is a necessary evil of democracy, I guess. (Branimir)

Populism was not recognised as a "special phenomenon" but rather as a common characteristic of big parties. It was often perceived as an attribute arising from the weak state of the Croatian political system in general. On the whole, our interviewees were very disappointed in Croatian political institutions, politicians and political parties.

The few of our interviewees who did mention more obvious instances of populism primarily mentioned the case of Milan Bandić and Željko Kerum. Interviewees primarily viewed their political style as a more intense example of populism in mainstream politics. Few of them considered a high level of populism among the mainstream political parties as uniquely Croatian feature.

\subsection{The search for the "breeding ground" for populism: The three core concepts of populism and the issue of mainstream populism}

As mentioned previously, the core features of populism can be summed up in three concepts: the "bad elite", the "good people" and the "general will" (Mudde, 2004). We analysed the interviews searching for political attitudes analogous to the core concepts of populism. Undoubtedly, if the potential electorate shares the core concepts (ideas) of populism, it is more susceptible to populist political projects. In other words, the electorate would become a potential "breeding ground" for the political and electoral demand of populist parties. The first concept, the perspective that the elite is corrupted and "bad", was almost undivided among our interviewees and quite strong, as vividly illustrated by the following quotes: 
Politicians, which are not doing anything, they have high salaries, they are corrupt, they steal from the people... from the people, from the state, they haven't done anything good. (Didi)

They are all the same, yes! [...] They are all one and the same gang. (Vida)

Really, using his power [politicians, and particularly party leaders] over the people for his interest only and not for other people. (Hrvoje) In contrast to the perspective on the political elite as corrupt, when discussing ideal politics, many of our interviewees stressed the need for a political system defined by greater emphasis on the needs of the so called ordinary people, which brings us to another core concept: the "general will". This concept has its analogy in the views that the people should be listened to more and should have more influence on politics. Many of our interviewees displayed such views:

Maybe democracy should function better, the people should be consulted more often, and the people should be listened to more. In fact, the politicians should be the ones that fulfil the wishes of the people, and not the other way around. (Ivan)

They [the politicians] decide about it all, but the people should be asked more often. They don't ask us anything, only when we need to vote! (Mirkec)

Most of the interviewees held the opinion that the "will of the people" can be unequivocally asserted in political practice. This frequent theme of the need to listen to/obey the "people" can also, to a degree, indicate a perception of the populus as a good and righteous political actor that should make the decisions directly. The "good people" concept in Mudde's (2004) interpretation of populism is connected to the concept of "general will", and cannot be viewed separately. Furthermore, in the case of this core concept, it is the role of the populist leader to unite the disparate political demands in the chain of equivalence (Laclau, 2005b). Logically, the core concept of "good people" cannot be as salient as the other two prior the rise of the populist political actors that call upon the "good people" and bring about the unification of the populus. Our analyses indicated the relative strength of the populist core concepts among the interviewees' political attitudes, indicating a potential "breeding ground" for populism. 


\subsection{The search for the "breeding ground" for populism: The "usual suspects" ideologies}

As already stated, populism is a thin-centred political ideology. It relies on a small number of core concepts and can come in combination with various ideologies. Therefore, the main radical ideologies that blend with populism must be understood and, in Laclau's (2005b) terms, the ideas for the formation of signifiers must be provided. This study primarily focuses on xenophobic nationalism ${ }^{17}$ and radical egalitarianism ${ }^{18}$ because these two ideologies are common core contents of international right-wing and left-wing populism and are important in the Croatian political and socio-historical context.

Many of our interviewees discussed the strong nationalism present among a certain part of the Croatian population and some discussed its connection to the Roman Catholic religion. For example:

The Croats are very sensitive to, I mean, to that "Croatian pride",

I mean, nationality, "we the Croats", "God and the Croats", that is strongly emphasized in the case of a great number of Croats. (Tara)

One of the most important factors of national identity for Croats is the Homeland War. As an ethnic conflict of grand scale, the event had a dominant role in constructing the notion of "important others", or in this case, the "unwanted others/enemies", i.e. the Serbs. Our interviewees held that some degree of suspicion towards Serbs, and even animosity, still exists in a part of the population:

The hatred towards the Serbs, let's say, it can be felt, the hatred exists. (Bob)

In addition, several of our interviewees displayed such attitudes themselves:

Because the Serbs, they always want some kind of quarrel. [...]. That means they always start something. (Vicko)

Such antagonistic views can "open the doors" for xenophobic and radical nationalist behaviour/ideas and make the context suitable for right-wing populism (Rydgren, 2007; Mudde, 2007). A few of our interviewees said that there could be a chance for some kind of radicalism in Croatia if economic situation worsens even further, as clearly stated in this quote:

\footnotetext{
17 According to Laclau (2005b: 193), in Eastern Europe "an ethnic populism trying to enhance the particularism of the national values of specific communities" can primarily be found.

18 Radical egalitarianism was an ideological component of socialist states like Yugoslavia (1945-1990) and is an important core ideology of left-wing populism (March, 2012).
} 
Let's say, if the standard of living fell even more, if the unemployment rose to maybe 500,000, there is clearly a ground for extreme parties to operate. This means that people are easily captivated by the nationalistic enthusiasm here, and if the situation became any worse... (Branimir)

Radical egalitarian ideology has its historical connections with leftwing political projects ${ }^{19}$ and an important historical legacy in Croatia. Many of our interviewees expressed nostalgia for a more egalitarian economic system, or at least support for its fundamental elements, such as full employment, social housing, minimal social inequalities and overreaching economic and work security. In addition, most of our interviewees spoke negatively of the current economic situation and about the rising economic inequalities and poverty, which some perceive as the result of Croatia's transition to a market economy and its accession to the European Union. Such views can be illustrated with the following quotes:

My parents always say that before privatisation everything was better, that more care was paid to the workers, that capitalism is really slavery now. My mother constantly works overtime in the company where she is employed, and never gets paid for that. (Arijana)

Huh, well, if it wasn't for that period [the Yugoslav socialist period] we would not have the apartment which we own now. (Barbara).

Yugoslavia shouldn't have been broken apart. Life was better during the Tito period. They say so. There was work for everybody. (Hrvojka)

The analyses showed that there is a clear foundation for egalitarian ideologies, perhaps even the radical ones. The broader analyses of three populist core concepts and two common core value ideologies indicated that there is a potential "breeding ground" for populism in Croatia.

\subsection{The search for the "breeding ground" for populism: The "strong leader" issue}

The role of the leader is essential for the concept of populism as populist leaders attempt to construct a special link with the people. They often aim to concentrate power and to disregard the political elites and democratic processes, at least when they are not in power. Several interviewees spoke explicitly about their preference for stronger leadership from a few people or even from one "strong leader":

\footnotetext{
${ }^{19}$ It should be repeated that exclusionary right-wing populism also makes use of egalitarian ideology, often by advocating for the chauvinist welfare state (Mudde and Kaltwasser, 2013).
} 
I would get rid of all of them [politicians] and sometimes it really comes to me to, you know, to install one man, some kind of half-dictatorship, and things would really be better then. (Tara)

It would be better for us if we had someone like Putin, maybe a bit less radical. I wish that a person like him would take over and that all the power were concentrated in one person. Because now it is too much divided, and you have to settle with everybody, and that has lead us into this situation. (Dean)

To be honest, I think that in order to bring this state in order, I think that we need some kind of a (...) a regime where one person is in power. [...] I think that such person should be very well educated, with PhDs from several universities. First that, and then that person needs to be charismatic. [...] He does not need to be a 100\% Croat, but at least one of his parents should be Croatian. (Barbara)

Our interviewees had various ideas about the nature of the rule of a strong leader. Some of them seem to resemble the populist rule, some a variant of a technocratic rule, and some resemble authoritarian rule. Most participants adopted a mixture of positions in their narratives. Akkerman, Mudde and Zaslove (2014: 1327) recognised that "populist and elitist ideas are not necessarily mutually exclusive, but rather might overlap to some extent", and authoritarianism is one of the core features of radical rightwing populist ideology (Mudde, 2007). In fact, all the strong leader variants are compatible with populism, even the technocratic one. Therefore, we hold that the "strong leader" issue is highly relevant for the analysis of populism, particularly the radical right populism with authoritarian tendencies, a common type in Europe during the 2000s and 2010s (e.g. Mudde, 2007).

\section{Quantitative research}

In this section, the quantitative aspect of this study is described along with the rationale for the selection of variables included in the regression model, the construction of measures and the results.

\subsection{Rationale for the selection of the measured concepts}

Populism thrives on anti-elitist and anti-systemic attitudes (Canovan, 1999; Meny and Surel, 2002; Arditi, 2005; Mudde, 2007; Rydgren, 2007), which are the crucial preferences of a populist electorate (Norris, 2005). To assess anti-establishment and anti-elite attitudes, the attitudes 
towards corruption among politicians, satisfaction with democracy and trust in national institutions were measured. As noted earlier, the survey design limited authors to measuring attitudinal constructs primarily associated with right-wing populism. Authoritarianism can also be considered important in explaining right-wing populist preferences (Mudde, 2007, 2004; Flecker, 2004). As a measure of authoritarian attitudes, items on the justification of various types of politics-related violence were used.

To explore the prevalent political positioning of the youth, the leftright political ideology scale was included. The success of right-wing populism depends on radical nationalist or nativist attitudes and immigrant or ethnic grievances (Norris, 2005; Flecker, 2004; Van der Brug, Fennema and Tillie, 2005). The right-wing voters in Croatia have a stronger religious identity (Zakošek, 2010), so a measure of the attitude on the role of religious belief in politics was included. Measures of political knowledge and interest in politics were also included, even though both have ambivalent relationships to populism, political participation and voting (Soler-i-Martí, 2015; Levendusky, 2011).

\subsection{Measures}

Preference for a strong leader not constrained by parliament was measured by a single item within a set of questions assessing the desirability of governance of various political systems. Participants were asked to evaluate the item "having a strong leader who is not constrained by parliament" on a four-point scale (from 0 = very bad to 3 = very good).

Gender, age, location and education were considered to be the most important socio-demographic variables, and their effect on outcome variable was controlled for. Age, originally measured by date of birth, was later categorised into three categories (16-18, 19-21, and 22-25 years of age). Similarly, education - originally measured by 14 categories - was categorised into primary, secondary and tertiary level. Dummy coding was used before entering these measures into the regression equation. The lowest category for both variables (16-18 years for age and primary level for education) was used as a reference category.

Satisfaction with democracy ("On the whole, how satisfied are you with the way democracy works in Croatia?") and left-right ideology ("On the scale from 0 to 10 , where 0 is left and 10 is right, would you say that 
you personally are left or right wing?") were both assessed on an elevenpoint scale with higher values indicating stronger satisfaction with democracy and expression of right wing attitudes, respectively.

Attitudes towards the role of religion in politics and political corruption were assessed with items "Good politicians believe in god" and "Politicians are corrupt", respectively. Participants' level of interest in politics was also measured as a single item predictor. The two attitudes were measured on a five-point scale (from $0=$ strongly disagree to $4=$ strongly agree), whereas level of interest in politics was assessed on a four-point scale (from $0=$ not at all interested to $3=$ very interested).

In measuring justification for violence, participants were presented with eight scenarios and asked in which of them violence can be justified (e.g. to overthrow a government, to protect jobs from being cut or to protect your ethnic/racial group). A five-point scale with higher value indicating higher justification for violence was used. A justification for violence scale was created as a linear combination of these eight items (Cronbach's $\alpha=.93$ ).

With regards to trust in national institutions, participants expressed their level of trust in thirteen institutions and organisations on an elevenpoint scale, with higher value indicating higher trust. Only items referring to political institutions were included in the construction of the trust in national political institutions scale (Cronbach's $\alpha=.86$ ).

Attitudes towards minority groups were measured with six items (e.g. "Muslims make a positive contribution to society", "The police should be stricter with Roma") on a five-point scale. The items were combined into a marginally reliable scale (Cronbach's $\alpha=.70$ ), which was used as a measure of overall attitude towards minority groups (higher values indicated more positive attitudes towards minority groups).

Knowledge of national politics was assessed with items "Who is the head of the Croatian government?", "Who is the Croatian foreign minister?", and "What is the main ruling party or coalition in Croatia?". A knowledge of national politics index was created as a linear combination of the scores ranging from 0 (zero correct answers) to 3 (three correct answers). Internal reliability was low $(\mathrm{KR}-20=.58)$.

Predictor were entered into the regression model in a hierarchical, block-wise fashion. Socio-demographic variables were included in the first block whereas the remaining set of predictors was included in the second 
block. Predictors in both blocks were included in a model simultaneously using the enter method.

\subsection{Quantitative analysis results}

Young people in our sample expressed a moderate preference for a strong leader $(\mathrm{M}=2.53$; Table 1$)$. More than half of the participants $(54.7 \%)$ believed that having a strong leader not constrained by parliament is a very good or fairly good type of political system.

Table 1. Range, mean (M) and standard deviation (SD) of the outcome (Preference for a strong leader) and quantitative predictor variables

\begin{tabular}{lccc}
\hline & Range & $M$ & $S D$ \\
\hline Preference for a strong leader & $0-4$ & 2.53 & 1.24 \\
\hline Political corruption & $0-4$ & 3.06 & 0.88 \\
\hline Justification for violence & $0-32$ & 12.56 & 7.96 \\
\hline Trust in national political institutions & $0-50$ & 19.15 & 9.74 \\
\hline Satisfaction with democracy in Croatia & $0-10$ & 4.76 & 2.37 \\
\hline Left-right political ideology & $0-10$ & 4.95 & 2.38 \\
\hline Role of religion in politics & $0-4$ & 1.53 & 1.14 \\
\hline Attitudes towards minority groups & $0-24$ & 12.32 & 3.44 \\
\hline Interest in politics & $0-3$ & 1.26 & 0.91 \\
\hline Level of political knowledge & $0-3$ & 2.37 & 0.84 \\
\hline
\end{tabular}

On average, participants had a very negative attitude towards politicians $(\mathrm{M}=3.06)$, with $73.8 \%$ agreeing or strongly agreeing with the statement "Politicians are corrupt". Among all predictors, that attitude had the strongest correlation with preference for a strong leader suggesting the role of the "bad elite" concept in the description of populism (Table 2 ). The other two items depicting anti-systemic attitudes indicated that the youth have a low level of trust in national political institutions (M $=19.15$ ) and that they are neither dissatisfied nor satisfied with the way democracy works in Croatia $(M=4.76)$. Although the mean value on the scale of satisfaction with democracy points to a moderate level of satisfaction, it should be noticed that almost $40 \%$ of participants chose value 6 or higher on the scale ranging to 10, suggesting an overall high degree of dissatisfaction with democracy. These two anti-systemic items were correlated with the preference for a strong leader in the expected direction, but the effects were small. 


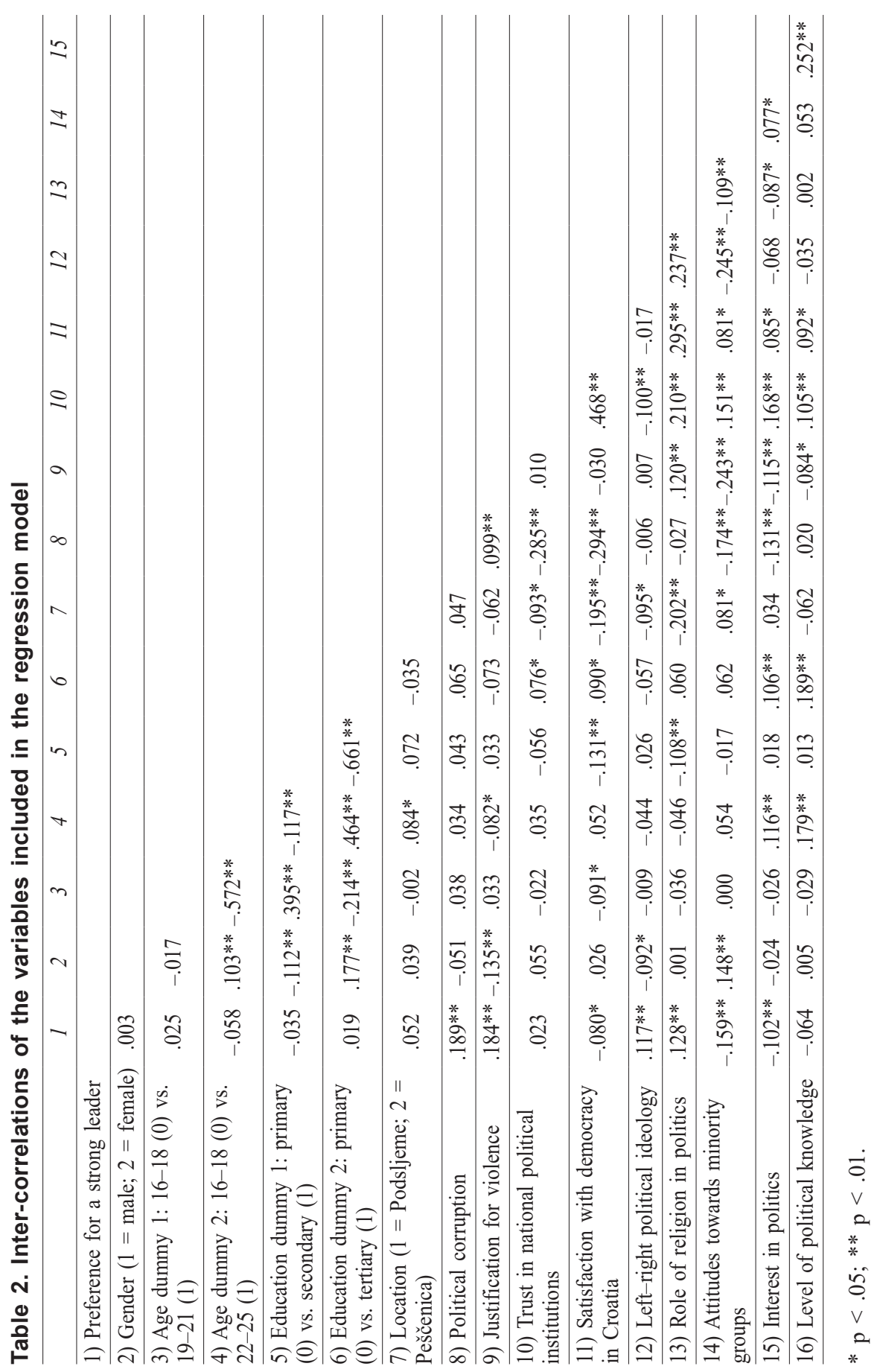


Authoritarianism, as a second core concept of populism, was measured with a composite measure of justification for violence. On average, participants expressed moderately low support towards using violence for achieving certain goals $(\mathrm{M}=12.56)$. As expected, justification for violence was positively correlated with preference for a strong leader $(\mathrm{r}=0.18)$.

We have assessed nativism as the third core concept of populism, with attitudes towards minority groups and towards religion's influence in politics. On average, young people expressed neither positive nor negative attitudes towards minority groups $(\mathrm{M}=12.32)$, whereas attitude towards religion's influence in politics suggested that young people on average have negative attitudes towards the role of religion in politics $(\mathrm{M}=1.53)$. Half of the participants from our sample disagree or strongly disagree with the statement "Good politicians believe in god". Both the association of that item and of attitudes towards minority groups both showed that stronger nativist sentiment leads to higher preference for a strong leader (Table 2).

Regarding self-positioning on a left-right political ideology scale, most participants placed themselves close to the mid-range value, with $37.8 \%$ selecting a neutral point on an eleven-point scale. Leaning towards right-wing ideology was positively correlated with preferences for a strong leader $(\mathrm{r}$ $=0.12$ ). Finally, young people, despite their relatively high knowledge of national politics ${ }^{20}(\mathrm{M}=2.37)$, expressed a relatively low interest in national politics $(M=1.26)$. More than two thirds of young people $(67.3 \%)$ are not very interested or not interested at all in politics. Higher interest in politics was negatively associated $(\mathrm{r}=-0.10)$, whereas political knowledge had no connection with the preference for a strong leader $(\mathrm{r}=-0.06)$.

At the multivariate level, multiple regression analysis was conducted with preference for a strong leader as the outcome. Socio-demographic variables included in the first step of the regression analysis accounted for only $1 \%$ of the variance of the outcome, indicating a non-significant increase in comparison to the null model (Table 3.). After the entry of nine predictors in the second step, the model significantly improved. It explained $11.9 \%$ of the variance in preference for a strong leader, and seven predictors proved statistically significant.

\footnotetext{
${ }^{20}$ More precisely, $47.9 \%$ of participants provided correct answers on all three questions, $31.6 \%$ had two correct answers, $11.8 \%$ had only one and $8.7 \%$ had zero correct answers. However, it should be emphasised that we measured knowledge on national politics with only three very basic questions, which presents a threat to the construct validity of this measure due to narrow operationalisation.
} 
Table 3. Regression analysis results for Preference for a strong leader as the outcome

\begin{tabular}{|c|c|c|c|c|c|c|}
\hline & & $B$ & $S E(b)$ & $\beta$ & $\operatorname{Adj} R^{2}$ & $\begin{array}{c}F \\
(d f 1, d f 2)\end{array}$ \\
\hline \multirow{7}{*}{$\frac{-}{\tilde{J}}$} & Constant & 2.38 & .22 & - & \multirow{7}{*}{.01} & \multirow{7}{*}{$\begin{array}{c}1.211 \\
(6,705)\end{array}$} \\
\hline & Gender & .00 & .09 & .00 & & \\
\hline & Age dummy 1 & -.05 & .16 & -.02 & & \\
\hline & Age dummy 2 & -.26 & .16 & -.10 & & \\
\hline & Education dummy 1 & -.01 & .17 & .00 & & \\
\hline & Education dummy 2 & .18 & .20 & .06 & & \\
\hline & Location & .16 & .09 & .06 & & \\
\hline \multirow{16}{*}{$\frac{v}{\frac{v}{z}}$} & Constant & 1.23 & .42 & - & \multirow{16}{*}{.119} & \multirow{16}{*}{$\begin{array}{l}6.269 * * \\
(15,696)\end{array}$} \\
\hline & Gender & .09 & .09 & .04 & & \\
\hline & Age dummy 1 & -.02 & .15 & -.01 & & \\
\hline & Age dummy 2 & -.17 & .15 & -.07 & & \\
\hline & Education dummy 1 & -.05 & .16 & -.02 & & \\
\hline & Education dummy 2 & .12 & .19 & .04 & & \\
\hline & Location & $.22 *$ & .09 & .09 & & \\
\hline & Political corruption & $.24 * *$ & .06 & .17 & & \\
\hline & Justification for violence & $.02 * *$ & .01 & .13 & & \\
\hline & Trust in national institutions & $.02 * *$ & .01 & .13 & & \\
\hline & $\begin{array}{l}\text { Satisfaction with democracy } \\
\text { in Croatia }\end{array}$ & $-.04 *$ & .02 & -.08 & & \\
\hline & Left-right political ideology & $.05^{*}$ & .02 & .09 & & \\
\hline & Role of religion in politics & $.10^{*}$ & .04 & .09 & & \\
\hline & $\begin{array}{l}\text { Attitudes towards minority } \\
\text { groups }\end{array}$ & $-.03 *$ & .01 & -.08 & & \\
\hline & Interest in politics & -.07 & .05 & -.05 & & \\
\hline & Level of political knowledge & -.05 & .06 & -.03 & & \\
\hline
\end{tabular}

$* \mathrm{p}<.05 ; * * \mathrm{p}<.01$.

Political corruption had the highest predictive value $(\beta=.17)$, followed by justification for violence scale and trust in national political institutions $(\beta=.13)$. The importance of these two variables in predicting preference for a strong leader points to the importance of the "bad elite" 
core concept and authoritarianism for populism. The bivariate association between the outcome and the scale of trust in national political institutions was supressed, as evident from the statistically significant beta value ( $\beta=$ .13 ) and the non-significant bivariate correlation (Table 2). Predictors of satisfaction with democracy, left-right political ideology, role of religion in politics and attitudes towards minority groups were significant at $\mathrm{p}<$ .05 , with modest beta weights. Lastly, the interest in politics and level of political knowledge proved to be non-significant as predictors, despite a significant bivariate correlation of interest in politics with the outcome $(r$ $=-.10)$. All the associations were of the expected directions.

\section{Conclusions}

In this study, the "breeding ground" for populism among the youth in $\mathrm{Za}$ greb was analysed using the data obtained during 2012 and 2013 within the FP7 project MYPLACE. Mixed methods thematic analysis of 61 semistructured interviews and qualitative analysis on a survey sample of 1,216 young people aged 16-25 was employed. It is important to emphasise that the study results were situated in the context of an economic crisis in Croatia and the youths' general discontent with politics and politicians. The qualitative analysis indicated that such attitudes run deep among young people, who are alienated from the political system. Interviewees primarily viewed important political and even some civic institutions as dysfunctional, which indicated that there is a foundation for the demand for populist politics, as "the institutional system has to be [...] broken if the populist appeal is to be effective" (Laclau, 2005b: 177). Given the (mis)uses of the term populism in the political and media discourse in Croatia (cf. footnote 1), it is not surprising that only a minority of the interviewees were familiar with it, and they almost exclusively related it to the mode of communication that can be found in mainstream politics. Most of them recognised and condemned patterns of behaviour among the mainstream politicians and political parties that correspond to populist strategies (mainstream populism). Narratives about the "real" populist parties were noted in very few interviews, and they were connected to radical right populist actors in the West.

The qualitative analysis of interviewees opinions analogue to three core concepts of populism (the "good people", the "bad elite" and the "general will"; Mudde, 2004) indicated a potential "breeding ground" for radical populism among the youth in Croatia. Most of our interviewees 
considered political elites corrupt and dysfunctional ("bad elite"), and many emphasised that the people should have more direct influence on politics, communicating their opinions and needs almost univocally as a corrective to the "bad elite", pointing to the core concepts of "general will" and "good people". Interviewees also perceived a certain spread of nationalism and radical egalitarianism (common ideological features of populism) in the general population. In regard to nationalism, a few of our interviewees showed some suspicion towards Serbs and were somewhat prone to nationalist attitudes. ${ }^{21}$ Regarding egalitarianism, many interviewees demanded more equality and a strong social economy with high levels of economic and job security. Several interviewees were nostalgic about the egalitarian socialist Yugoslav past. $^{22}$

A few of the interviewees spoke explicitly of their preference for a leader with great powers to pull the country out of hardships. They expressed the desire for one person to end the "endless arguing" of governments and oppositions and to follow the "real" needs of the "people", thus disrupting the usual democratic process and concentrating the political executive power in the function to carry out the will of the "people" and "make things better for the "people". Such preferences correspond to a populist type of rule, not ignoring its authoritarian contents (see the introduction and particularly the aim of the study sections for a more detailed review of the issue). Interviews have also established that young people in Zagreb have rather limited knowledge of history, particularly regarding the critical assessment of the contested periods of Croatian political past. $^{23}$ That indicates a possible absence of crucial safeguards against the rise of new radical political projects.

In the quantitative part of this study, the analysis was narrowed and focused to a single dimension of populism: its radical right-wing variant.

\footnotetext{
${ }^{21}$ Survey results corroborated insights from the interviews and showed that $21.8 \%$ of participants agreed or strongly agreed with the statement "You can never be careful enough with Serbs", whereas $42.8 \%$ of participants disagreed or strongly disagreed with this statement. In line with this, many interviewees criticised nationalism that spreads intolerance towards Serbs.

${ }^{22}$ Of course, the demands for greater economic and job security can be interpreted as demands for a strong social welfare state such as the Nordic Welfare State systems, presently under a dismantling process (Baeten, Berg and Hansen, 2015).

${ }^{23}$ For example, the period of the Independent State of Croatia, a fascist puppet state (1941-1945), or the period of socialist Yugoslavia (1945-1991).
} 
Accordingly, the aim of our quantitative analysis was to examine the connections of a battery of survey questions indicating radical right populism to the type of political radicalism that supports a political system with a strong leader not constrained by the institution of the democratic parliament (the outcome variable).

Searching for the predictors of the demand-side populism among the population is a demanding task as (potential) voters are always more heterogeneous than most studies expect (Mudde, 2007). Thus, it is not surprising that our regression model accounted for a modest amount of variance of the preference for a strong leader (11.9\%). In spite of that, the results indicated that two predictors - attitudes towards political corruption and justification of violence - had a notable contribution in explaining the preference for a strong leader. The importance of political corruption is in line with the importance of anti-elitist and anti-systemic attitudes in populism (Canovan, 1999; Meny and Surel, 2002; Arditi, 2005; Mudde, 2007; Rydgren, 2007). Regression analysis results indicated a slight skew to the right on the political spectrum of youth who are more inclined to support strong leaders. Many studies on the radical right variant of populism (Mudde, 2007; Flecker, 2004; Norris, 2005; Turner, 2009 [2005]; Kymlicka, 2003) emphasised the role of nativist, anti-immigrant and xenophobic attitudes as some the most significant predictors of populism.

This research indicated the existence of the "breeding ground" for populism among Croatian youth. However, it should be highlighted that it is a "notorious fact that young people faithfully mirror the image of society in which they grew up" (Ilišin, 2015: 41). The analyses demonstrated that the youth is prepared to consider significant changes to get better political leadership and a better life, even if it means rejecting some dimensions of the representative liberal democratic system and choosing a strong leader to govern the country. Regardless of the identified inclinations towards populism, there were no relevant populist actors and parties in Croatia at the time the research was conducted. This may be due to a supply-side issue, perhaps the most important factor being the democratisation stimulated by the institutional and the political influence of the European Union (Beširević, 2012; Dolenec, 2013). However, the size of the economic crisis in Croatia and the level of dissatisfaction with the two biggest political parties in Croatia (and their traditional coalition partners) could open doors for various protest parties. Nevertheless, the demand-side analysis is lim- 
ited, and wide support for the ideas of democracy exists in Croatia, which is confirmed both in the qualitative and quantitative results of this study. Therefore, the realisation of inclinations to populist alternatives depends on many factors, not alone the supply of potent populist actors. As Van der Brug, Fennema and Tillie (2005) emphasised, a vote aimed at punishing political elites is qualitatively different from a regime protest vote, one that aims to change the political system and main political ideologies.

The study was limited by several notable shortcomings. Despite probabilistic sampling, relatively low contact and response rates may have been a source of bias in the sample selection. In addition, the results of this study cannot be generalised to the entire youth population of Zagreb or Croatia as sampling was limited to two city districts. Nonetheless, the authors believe that the results are indicative of socio-political trends specific to the Croatian context and useful given the lack of research on the phenomenon. Measures used for operationalisation of key constructs were limited as well. The shortcomings of using a single item of preference for a strong leader as a measure of populism are addressed in detail throughout the study. However, the findings of significant correlations between strong leader preference and anti-elite and some right-wing attitudes are indicative of its construct validity. Populism is generally an under-researched phenomenon in Croatia, and demand-sides studies such as this one are still rare even in the international literature. Reliable and valid quantitative measures of populist preference are still under development, and the attempts made by Akkerman, Mudde and Zaslove (2014) are commendable. However, at the time the MYPLACE project was conceptualised (2010-2011), populism was primarily considered a right-wing phenomenon and our survey was designed accordingly. Using justification of violence as a proxy measure of authoritarianism, as well as measuring knowledge on national politics with only three items undermined validity of the measures. The authors emphasise the need for better operationalisation of such constructs in future research. Likewise, the measurement of constructs such as role of religion in politics and political corruption with more than one item would certainly increase their metric properties. Finally, cross sectional design of the study prevents any inference of causality between predictors and the outcome. Instead, the relationship is exclusively driven by theory. As for the qualitative part of the research, it should be considered primarily as a broad contextualisation of populism amongst the youth in Zagreb, suitable to the 
explorative character of this study and the under-researched, elusive, phenomenon of populism. Further research is needed to explore the character of youth inclinations towards populism, as well as their protest against the political elites in Croatia and the system they shaped. Thus, an in-depth examination of youth understanding of the concept of democracy and their knowledge of the "dark sides" of historical radical political regimes should be conducted.

\section{Acknowledgements}

We are grateful to anonymous reviewers for their helpful and constructive inputs, as well as to all of the participants who took part in this research.

\section{REFERENCES}

Akkerman, Agnes, Mudde, Cas and Zaslove, Andrej (2014). "How Populist Are the People? Measuring Populist Attitudes in Voters", Comparative political studies, 49 (7): 1324-1353. doi: 10.1177/0010414013512600

Albertazzi, Daniele and McDonnell, Duncan (2008). "Introduction: The Sceptre and the Spectre", in: Daniele Albertazzi and Duncan McDonnell (eds). TwentyFirst Century Populism: The Spectre of Western European Democracy. New York: Palgrave, pp. 1-11. doi: 10.1057/9780230592100

Arditi, Benjamin (2005). "Populism as an Internal Periphery of Democratic Politics", in: Francisco Panizza (ed). Populism and the Mirror of Democracy. London: Verso, pp. 72-98.

Baeten, Guy and Berg, Lawrence D. and Hansen, Anders Lund (2015). "Introduction: Neoliberalism and post-welfare Nordic states in transition", Geografiska Annaler, Series B: Human Geography, 97 (3): 209-212. doi: 10.1111/geob.12075

Beširević, Nataša (2012). "Demokratizacija i europeizacija kao teorijski okviri instrumenta uvjetovanosti u 'politici proširenja' Europske Unije" [Democratisation and Europeanisation as theoretical frame of conditionality in the European Union Enlargement policy], Političke perspektive, 2 (1): 21-44.

Burawoy, Michael (2009). The Extended Case Method: Four Countries, Four Decades, Four Great Transformations, and One Theoretical Tradition. Berkeley: University of California Press.

Canovan, Margaret (1999). "Trust the People! Populism and the Two Faces of Democracy", Political Studies, 47 (1): 2-16. doi: 10.1111/1467-9248.00184

Creswell, John, W. (2013). Qualitative Inquiry and Research Design: Choosing Among Five Approaches. London: SAGE.

Dolenec, Danijela (2013). Democratic Institutions and Authoritarian Rule in Southeast Europe. Colchester: European Consortium for Political Research Press.

Eurostat (2014). Basic figures on the EU - Winter 2013/2014 edition. http:// ec.europa.eu/eurostat/documents/4031688/5931440/KS-GL-13-004-EN. $\mathrm{PDF} / 8 \mathrm{~b} 83 f f 8 d-2737-441 \mathrm{f}-\mathrm{af} 78-9714$ ca46549f?version=1.0 
Flecker, Joerg (2004). Socio-economic change, individual reactions and the appeal of the extreme right. Brussels: European Commission.

Franc, Renata and Međugorac, Vanja (2015). "Mladi i (ne)povjerenje u institucije: moguće odrednice i posljedice" [Youth and (dis)trust in institutions: Possible determinants and consequences], in: Vlasta Ilišin, Anja Gvozdanović and Dunja Potočnik (eds). Demokratski potencijali mladih u Hrvatskoj [Democratic potential of youth in Croatia]. Zagreb: Centar za društvena istraživanja u Zagrebu i Centar za demokraciju i pravo Miko Tripalo, pp. 47-63.

Franc, Renata, Šakić, Vlado and Maričić, Jelena (2007). "Građanski aktivizam u Hrvatskoj” [Civil Activism in Croatia], Društvena istraživanja, 16 (1-2): 111-132.

Freeden, Michael (1998). Ideologies and Political Theory: A Conceptual Approach. Oxford: Clarendon. doi: 10.1093/019829414X.001.0001

Gidron, Noam and Bonikowski Bart. (2013). "Varieties of Populism: Literature Review and Research Agenda", Weatherhead Working Paper Series, 13-0004: $1-38$.

Grbeša, Mirjana and Šalaj, Berto (2014). Faces of Populism in Croatia. Paper presented at the IPSA Conference, Montreal, July 2014.

Gvozdanović, Anja (2011). "Some Indicators of Political Culture of University Students in Croatia", Sociologija i prostor, 48 (3): 461-477.

Gvozdanović, Anja (2014). "Politički utjecaj i vrijednosti kao odrednice političkog povjerenja mladih u Hrvatskoj" [Political Influence and Values as Determinants of Political Trust among Youth in Croatia], Revija za sociologiju, 44 (1): 5-30. doi: 10.5613/rzs.44.1.1

Gvozdanović, Anja (2015). "Izvori socijalnog povjerenja studenata u Hrvatskoj" [Sources of Croatian university students' social trust], in: Vlasta Ilišin, Anja Gvozdanović and Dunja Potočnik (eds). Demokratski potencijali mladih u Hrvatskoj [Democratic potential of youth in Croatia]. Zagreb: Centar za društvena istraživanja u Zagrebu i Centar za demokraciju i pravo Miko Tripalo, pp. 65-91.

Ilišin, Vlasta (1999). Mladi na margini društva $i$ politike [Young People at the Margins of Society and Politics]. Zagreb: Alinea.

Ilišin, Vlasta (2004). "Politička participacija mladih i politika prema mladima: Hrvatska u europskom kontekstu" [Political Participation of Young People and Youth Policy: Croatia in the European Context], Politička misao, 40 (3): 37-57.

Ilišin, Vlasta (2006). Mladi u lokalnoj vlasti u Hrvatskoj [Young People's Participation in the Local Government in Croatia]. Zagreb: Demokratska inicijativa mladih.

Ilišin, Vlasta (2015). "Paradoksi demokratskog potencijala suvremene generacije mladih" [Paradoxes of contemporary young generation's democratic potential], in: Vlasta Ilišin, Anja Gvozdanović and Dunja Potočnik (eds). Demokratski potencijali mladih u Hrvatskoj [Democratic potential of youth in Croatia]. Zagreb: Centar za društvena istraživanja u Zagrebu i Centar za demokraciju i pravo Miko Tripalo, pp. 15-45.

Ilišin, Vlasta, Bouillet, Dejana, Gvozdanović, Anja and Potočnik, Dunja (2013). Mladi u vremenu krize [Young People in the Times of Crisis]. Zagreb: Institut za društvena istraživanja u Zagrebu. 
Kaltwasser, Cristóbal Rovira (2012). "The ambivalence of populism: threat and corrective for democracy", Democratization, 19 (2): 184-208. doi: $10.1080 / 13510347.2011 .572619$

Kasapović, Mirjana (2015). "Sinčićeva retorika radikalni je oblik desnog populizma" [Sinčić's Rhetoric is a Radical Form of the Right-Wing Populism], Večernji list, January 15. http://www.vecernji.hr/hrvatska/sinciceva-retorika-radikalni-je-oblik-desnog-populizma-984617.

Kymlicka, Will (2003 [1995]). Multikulturalno građanstvo: liberalna teorija manjinskih prava [Multicultural Citizenship: A Liberal Theory of Minority Rights]. Zagreb: Jesenski i Turk.

Laclau, Ernesto (2005a). "Populism: What's in a Name?", in: Francisco Panizza (ed). Populism and the Mirror of Democracy. London: Verso, pp. 32-50.

Laclau, Ernesto (2005b). On populist reason. London: Verso.

Levendusky, Matthew S. (2011). "Rethinking the role of political information", Public Opinion Quarterly, 75 (1): 42-64. doi: 10.1093/poq/nfq070

March, Luke (2012). "Problems and perspectives of contemporary European radical left parties: Chasing a lost world or still a world to win?", International Critical Thought, 2 (3): 314 -339. doi: 10.1080/21598282.2012.706777

March, Luke and Mudde, Cas (2005). "What's left of the radical left? The European radical left after 1989: Decline and mutation", Comparative European Politics, 3 (1): 23-49. doi: 10.1057/palgrave.cep.6110052

Maxwell, Joseph A. and Margaret Chmiel (2014). "Notes Toward a Theory of Qualitative Data Analysis", in: Uwe Flick (ed.). The SAGE Handbook of Qualitative Data Analysis. London: SAGE, pp. 21-35. doi: 10.4135/9781446282243.n2

Meny, Yves and Surel, Yves (2002). "The Constitutive Ambiguity of Populism", in: Yves Meny and Yves Surel (eds). Democracies and the Populist Challenge. Basingstoke: Palgrave, pp. 1-21.

Merkel, Wolfgang (2004). "Embedded and defective democracies", Democratization, 11 (5): 33-58. doi: 10.1080/13510340412331304598

Milardović, Anđelko (2004). Populizam i demokracija [Populism and Democracy]. Zagreb: Centar za politološka istraživanja.

Mouffe, Chantal (2013). Agonistics: Thinking the World Politically. London: Verso.

Mudde, Cas (2002). "In the name of the Peasantry, the Proletarian, and the People: Populism in Eastern Europe", in: Yves Meny and Yves Surel (eds). Democracies and the Populist Challenge. Basingstoke: Palgrave, pp. 214-232.

Mudde, Cas (2004). "The Populist Zeitgeist", Government and Opposition, 39 (4): 542-563. doi: 10.1111/j.1477-7053.2004.00135.x

Mudde, Cas (2007). Populist Radical Right Parties in Europe. New York: Cambridge University Press. doi: 10.1017/S0022381608080511

Mudde, Cas (2015). "Populism in Europe: a primer", openDemocracy, May 12. https:/www.opendemocracy.net/can-europe-make-it/cas-mudde/populism-ineurope-primer.

Mudde, Cas and Kaltwasser, Cristóbal Rovira (2013). "Exclusionary vs. Inclusionary Populism: Comparing Contemporary Europe and Latin America", Government and Opposition, 48 (2): 147-174. doi: 10.1017/gov.2012.11 
Mustapić, Marko and Karajić, Nenad (2013). "Studenti i društveni problem: imaju li preferencije političkih stranaka što s tim?" [Students and Social Problems: Do Political Party Preferences Have Anything to Do with It?], Revija za sociologiju, 43 (2): 107-131. doi: 10.5613/rzs.43.2.1

Norris, Pippa (2005). Radical Right: Voters and Parties in the Electoral Market. Cambridge: Cambridge University Press.

Offe, Claus and Adler, Pierre (1991). "Capitalism by Democratic Design? Democratic Theory Facing the Triple Transition in East Central Europe", Social research, 58 (4): $865-892$.

Panizza, Francisco (2005). "Populism and the Mirror of Democracy", in: Francisco Panizza (ed). Populism and the Mirror of Democracy. London: Verso, pp. $1-31$.

Rydgren, Jens (2007). "The Sociology of the Radical Right", Annual Review of Sociology, 33: 241-262. doi: 10.1146/annurev.soc.33.040406.131752

Sekulić, Duško and Šporer, Željka (2010). “Gubimo li povjerenje u institucije?" [Are We Loosing Trust in Institutions], in: Josip Kregar, Duško Sekulić and Željka Šporer (eds). Korupcija i povjerenje [Corruption and Trust]. Zagreb: Centar za demokraciju i pravo Miko Tripalo i Pravni fakultet Sveučilišta u Zagrebu, pp. 71-117.

Soler-i-Martí, Roger (2015). "Youth political involvement update: measuring the role of cause-oriented political interest in young people's activism", Journal of Youth Studies, 18 (3): 396 -416. doi: 10.1080/13676261.2014.963538

Stavrakakis, Yannis and Katsambekis, Giorgos (2014). "Left-wing populism in the European periphery: the case of SYRIZA", Journal of Political Ideologies, 19 (2): 119-142. doi: 10.1080/13569317.2014.909266

Šalaj, Berto (2012). "Suvremeni populizam" [Contemporary Populism], Anali Hrvatskog politološkog društva, 9 (1): 21-49.

Tomić-Koludrović, Inga (1999). "Skeptična generacija u protumodernizacijskom kontekstu" [Sceptical Generation in Counter-Modernizing Context], Politička misao, 36 (3): 175-193.

Tsakatika, Myrto and Eleftheriou, Costas (2013). "The Radical Left's Turn towards Civil Society in Greece: One Strategy, Two Paths", South European Society and Politics, 18 (1): 81 - 99. doi: 10.1080/13608746.2012.757455

[Turner, Jonathan H.] Tarner, Džonatan H. (2009 [2005]). Sociologija [Sociology]. Novi Sad: Mediterran Publishing; Beograd: Centar za demokratiju.

Van der Brug, Wouter, Fennema, Meindert and Tillie, Jean (2005). "Why some anti-immigrant parties fail and others succeed: A Two-Step Model of Aggregate Electoral Support", Comparative Political Studies, 38 (5): 537-573. doi: 10.1177/0010414004273928

Werts, Han, Scheepers, Peer and Lubbers, Marcel (2012). "Euro-scepticism and radical right-wing voting in Europe, 2002-2008: Social cleavages, socio-political attitudes and contextual characteristics determining voting for the radical right", European Union Politics, 14 (2): 183-205. doi: 10.1177/1465116512469287

Yin, Robert K. (2003). Case Study Research: Design and Methods. London: SAGE. 
Yin, Robert K. (2010). Qualitative Research from Start to Finish. New York: Guilford Press.

Zakošek, Nenad (2010). “Zauzdani populizam: fenomen Milana Bandića” [Restrained Populism: The Phenomenon of Milan Bandić], Političke analize, 1 (1): $6-10$.

Zakošek, Nenad (2015). "Globusov okrugli stol - populizam u Hrvatskoj. Populizam je znak bolesti naše demokracije" [The Globus magazine round table Populism in Croatia. Populism is a sign of illness of our democracy], Jutarnji list, November 25. http://izbori.jutarnji.hr/globusov-okrugli-stol-ljevica-u-hrvatskoj-i-europi-populizam-je-znak-bolesti-nase-demokracije-socijaldemokracijanema-odgovor-na-ekonomsku-krizu/.

Zaslove, Andrej (2008). "Here to Stay? Populism as a New Party Type", European Review, 16 (3): 319-336. doi: 10.1017/S1062798708000288

\title{
Mladi u Hrvatskoj i populizam: analiza "plodnog tla« za razvoj populizma među mladima u gradu Zagrebu primjenom mješovite metode
}

\author{
Augustin DERADO \\ Institut društvenih znanosti Ivo Pilar - Područni centar Split, Hrvatska \\ augustin.derado@gmail.com \\ Vanja DERGIĆ \\ Zagreb, Hrvatska \\ vanjadergic@gmail.com
}

Vanja MEĐUGORAC

Institut društvenih znanosti Ivo Pilar, Zagreb, Hrvatska

vanja.medugorac@pilar.hr

Recentne međunarodne studije izvještavaju o porastu izbornog uspjeha populističkih političkih stranaka među mlađom populacijom. U ovom je radu istraženo postoji li »plodno tlo« za prihvaćanje populizma među mladima u Zagrebu na temelju hrvatskih rezultata projekta Memory, Youth, Political Legacy and Civic Engagement (MYPLACE). Korištena je mješovita metoda - tematska analiza 61 polustrukturiranog intervjua i regresijska analiza provedena na anketnim podacima prikupljenim na uzorku od 1.216 mladih u dobi od 16 do 25 godina. Kvalitativna je analiza indicirala postojanje analogija u političkim stavovima intervjuiranih mladih s trima idejama koje su u temelju modela populizma Casa Muddea (»narod je dobar i pravedan«, "politička elita je pokvarena« i »treba se provoditi opća volja naroda«). Također, dio je sugovornika zastupao neke od uobičajenih ideoloških komponenti populizma - nacionalizam i radikalni egalitarizam. U kvantitativnom dijelu rada analiza je sužena na samo jednu dimenziju populizma - radikal- 
nu desnu varijantu. S obzirom na to da u vrijeme istraživanja u Hrvatskoj nisu postojale utjecajnije populističke stranke, analiza je s podržavanja političkih stranaka usmjerena na podržavanje ideja. Za kriterijsku varijablu regresijske analize izabrana je preferencija političkog sustava s jakim vođom koji nije pod kontrolom parlamenta. Ta preferencija, uz autoritarna svojstva, sadržava i jak populistički potencijal u suvremenim demokracijama. Analize su pokazale da su stavovi protiv elita i protiv sustava institucija kod mladih povezani s preferencijom nedemokratskoga jakog vođe, kao i autoritarnost te nekoliko radikalnijih desnih stavova. I kvalitativni i kvantitativni nalazi upućuju na to da postoji plodno tlo za razvoj populizma među mladima u Zagrebu, no potrebne su daljnje studije kako bi se istražio taj kompleksan i u Hrvatskoj dosad gotovo neistražen fenomen.

Ključne riječi: mladi, populizam, demokracija, autoritarnost, radikalni desni populizam 